\title{
МИШКО ШУВАКОВИЋ
}

Универзитет уметности у Београду, Факултет музичке уметности - Катедра за музикологију, Београд

DOI 10.5937/kultura1547052S

УДК 316.774:004]:111.852

7.01:316.774

оригиналан научни рад

\section{CKИLE $3 A$ TEOPHJY HOBИXMEДИJA}

Сажетак: Текст Скице за теорију нових медија предлаже отворене проблеме за еклектичну расправу нових медија у пољу савремене естетике и теорије уметности. Указује се на статус новомедијског уметничког дела и на замену концепта уметничког дела уметничким диспозитивом. Појам диспозитива се преузима из теорије Мишела Фукоа и филозофије Борђа Агамбена. Појам диспозитива примењен на теоретизације нових медија се показује на отворен, променьив и прочесуалан начин. Ту се указује на прелаз од појма релаиијске естетике Николаса Буриоа на појам процесуираних односа и тиме на динамизиран концепт уметничког диспозитива. Повезивањем техне са епистемом и афектом успоставља се основа за политизаиију уметности и за разматрање политике уметности. Појам политике уметности се разматра референтно према Жаку Рансијеру и Габријелу Рокхилу. У другом делу текста се редефините појам нових медија у историјској перспективи: од авангарди преко неоавангарди до савремене уметности.

Кључне речи: нови медији, диспозитив, процесуирање, политика, авангарда, неоавангарда, савремена уметност

... не знамо ништа о нашим чулима док медиј не прибави моделе и метафоре... ${ }^{1}$

\section{Постављање проблематике}

Традиционално рано античко раздвајање ${ }^{2}$ техне и епистеме - умећа и знања - као да више не постоји на тако очигледан начин у савременој уметности. Није тешко уважи-

1 Kittler, F. (2010) Optical media: Berlin Lectures 1999, Cambridge: Polity. p. 34.

2 Stiegler, B. (1998) General Introduction, p. 1. Упоредити ca: Hintikka, J. Knowing How, Knowing That and Knowing What: Obsservations on their 
МИШКО ШУВАКОВИЋ

ти тезу „да нема епистеме уметности”з у општем смислу, пошто уметност јесте укључена у сасвим појединачне и фрагментиране друштвене антагонизме и борбе. Али, сви ти појединачни антагонизми и борбе морају бити рефлектовани у трагању за разлозима за техничке потенцијалности и афективне учинке као одговоре или, чак, инстинктивне реакције на антагонизме и борбе. Зато, знање у појединачним случајевима процесуирања уметности није холистичко конзистентно теоријско тело, већ променљива тактичка мапа испуњена појединачним одношеним и динамизираним језичким репрезентима епистемама, а не општим епистемолошким оквиром који интегрише на холистички начин знање о или у уметности. Постоје тактичке секције мапа које се испуњавају појединачним знањима за које се траже одговарајући динамични односи.

Повезаност, тачније, прожетост техне и епистеме у савременим уметничким праксама условљена је отвореним, нестабилним, еластичним и променљивим технолошким, телесним и концептуалним медијацијским функцијама које се успостављају између сложених и хибридних области деловања са афективним, перформативним или политичким естетским учинцима. Реч је о успостављању процесуираног односа између техничке потенцијалности (техне), извршног поретка знања (епистеме) и интензитета чулне редистрибуције ефеката (афект) помоћу новомедијске уметничке праксе. Термин „процесирање”, при томе, реферира двосмислено - метафорично - по употребном значењу на (а) правни термин „процесирање”: подвргавање злочина или осумњичене/осумњиченог судском поступку; и (б) на софтверски термин processing ${ }^{4}$ за означавање програмског језика и интегративног развојног окружја за визуелно пројектовање репрезентација уметничких, научних или медијских знања, односно, за визуелно организовање пројеката. Тај процесирани однос између техне, епистема и афект се визуелизира на доњем дијаграму:

техне

епистема

новомедијска пракса

\section{афект}

Таблица 1 Троугаони однос нових медија према техници, знању и интензитету дејства

Relation in Plato and Other Greek Philosophers, eds. Harrison, C. and Orton, F. (1984), p. 47-56.

3 Rancière, J. (2004) The Politicos of Aesthetics, The Distribution of the Sensible, London: Continuum, p. 228-229.

4 Видети: http://processingjs.org. 


\section{МИШКО ШУВАКОВИЋ}

Повезивање техне са епистемом и афектом последица је савремене медијске отворености, нестабилности и флексибилности како уметности тако и културе и друштва. Техничке потенцијалности и извршни поредак знања у датој култури и друштву су усмерени на постигнуће интензивног дејства које доводи до промене чулног поретка и начина дистрибуције чулности у односу појединца и било које стварне или потенцијалне заједнице. Та промена мора да буде реконцептуализована и истовремено реидеологизирана у односу на свакодневни локални и глобални контекст. Ова теза подсећа на славни Адорнов став из Естетичке теорије:

„Постало је само по себи разумљиво да ништа што се тиче уметности, ни у њој самој ни у њеном односу спрам целине, није више само по себи разумљиво, па чак ни њено право на егзистенцију."

У савременом уопштењу може се рећи да је постало јасно да ништа што се тиче уметности и њених сложених окружја од света уметности и уметничких инфраструктура до културе и друштва није по себи разумљиво те захтева процесуирање епистеме тј. увођење извршних знања у производњу, дистрибуцију и рецепцију естетско-уметничких медијских ефеката.

Епистема, зато, није посредством техне средство - медиатор - за посредовање политичких метафизичких или политичких порука или текстуалних репрезентација, већ епистема се посредством техне „пакује” у имагинарне пакете узорака од којих се очекује афективно дејство којим се осећајно и интелигибилно преуређује тренутни специфицирани поредак облика живота. Ако се троугао епистема, техне и афекта у контексту нових медија схвати виталистички тада се контекст или инфраструктура њиховог ситуирања предочава као један појединачни облик живота. При томе, појам „облик живота” има два различита порекла:

- $\quad$ у језику прото-лингвистичке анализе: „замислити један језик значи замислити облик живота"; и

- у критичком моделу анализе политичког живота: „под термином форма-живота... мислим на живот који никада не може бити одвојен од својих облика, живот у коме никада није могуће изоловати нешто такво као што је голи живот"”.

5 Adorno, T. W. (1979) Estetička teorija, Beograd: Nolit, p. 25.

6 Wittgesntein, L. (1986) Philosophical Investigations, Oxford: Basil Blackwell, p. 19.

7 Agamben, G. Form-of-Life, eds. Virno, P. and Hardt, M. (1996), p. 152. 
МИШКО ШУВАКОВИЋ

Та два порекла термина „облик живота” указују на пресек у коме је „облик живота” истовремено протокол и сензитивно окружје испуњено живим догађајима за имагинарне узорке настале новомедијским радом у савременој уметности.

У савременим уметностима, зато, однос чулно-концептуалног режима и телесно-осећајних интуиција и инстинкта је политички у оном смислу у коме, на пример, Жак Рансијер (Jacques Rancière) говори о дистрибуцији чулности:

„Ово значи да естетска политика увек дефинише себе помоћу одређене расподеле улога у дистрибуцији чулног, реконфигурацији датих перцептивних форми."

Тиме се обликује друштвени микро или макро однос који се доживљава као медијски афективни догађај (нешто са последицама на затечене облике живота), а не као репрезент тј. медијатор унутар медијских слика (нешто као онтолошка илузија о афективном догађају). То значи да се чулно догађање покренуто савременим новомедијским и перформативним уметничким делом и, истовремено, концептуално рефлектовање изазваног афекта повезују у однос који је истовремено оно што осећамо и разумевамо у односу на стварност датог облика живота. Захтев за повезивањем осећања и разумевања се појављује у ситуацији када не постоји скуп канонских очекивања и медијских навика у пољу перманентног процесуирања уметности. Уместо канонских очекивања и медијских навика у пољу уметности - указује се повратак реалном дешавању у свакодневици. Повратак реалном није дат као референт дела и света, већ као конститутив новомедијског рада што новомедијске учинке поставља као дејствујуће пакете унутар затечене тренутне реалности.

У уметности перманентног процесуирања завршено и постављено уметничко дело, на начин о коме је Мартин Хајдегер (Martin Heidegger) говорио као о по-ставу ${ }^{9}$ (нем. gestell), бива замењено уметничким диспозитивом.

Концептуална конструкција уметничког дела као диспозитива (fr. dispositif, енглески превод: aparatus) односи се на уметност као епистемологизирану технологију којом се генеришу посебне врсте интензитета-афеката за телесно тј. живо опажање и присвајање артифицијелног аудиовизуелног, тактилног, бихејвиоралног уметничког или вануметничког догађаја, али и као институционализовани облици производње, размене, рецепције и потрошње уметности као

8 Rancière, J. Politicized Art, in: Rancière, J. (2004), p. 63.

9 Heidegger, M. Pitanje o tehnici, u: Uvod u Heideggera (1972), str. 105. 


\section{МИШКО ШУВАКОВИЋ}

културалног добра (културалног вишка вредности) којима се организују специфични облици телесног и културалног понашања непосредне и посредне публике.

Полазна одредница диспозитива се може наћи у једном интервјуу Мишела Фукоа (Michael Foucault):

„Оно што желим да изнесем са тим термином је, прво, потпуно хетерогени скуп кога чине дискурс, институције, архитектонски облици, регулационе одлуке, закони, административне мере, научни искази, филозофске, моралне и филантропске пропозиције - укратко све оно што је речено и неречено. Ово су елементи диспозитива. Диспозитив је систем односа који може бити успостављен између ових елемената. Друго, оно што покушавам да идентификујем у овом диспозитиву је управо веза која може постојати између ових хетерогених елемената. Тако, појединачни диспозитив може фигурисати једном као програм институције, а други пут може функционисати као средство просуђивања или маскирања праксе која сама остаје тиха, или као секундарна реинтерпретација ове праксе, отворена за ново поље рационалности. Укратко, између ових елемената, било дискурзивних или недискурзивних, постоји некаква међуигра померања позиција и модификовања функција које могу веома много варирати. Треће, ја разумем под термином диспозитив врсту, рећи ћемо, формације која има главну функцију у датом историјском тренутку да одговори на једну хитну потребу. Диспозитив има доминантну стратешку функцију."10

Ђорђо Агамбен је на овај начин постављени концепт диспозитива проширио следећим речима:

„Дословно ћу назвати диспозитивом било шта што има на неки начин способност да ухвати, оријентише, моделује, контролише или осигура гестове, понашање, мишљење или дискурсе живих створења."11

Тада се диспозитив у општем смислу може разумети као динамична и интерактивна инфраструктура појединачног облика живота у неком временском тренутку и у неком геоурбаном простору.

Ако се концепт диспозитива примени на уметност, тада се може извести следећа конструкција. Диспозитив уметности као трансформисани појам уметничког дела је активни или

10 Foucault, M., Wajemanom, G., Millerom, J. A., Le Gaufeyom, G., Celasom, D., Millerom, G., Millot, C., Joceyne, L. and Miller, J. The Confession of the Flesh, in: Gordon, C. (1980), p. 194-196.

11 Agamben, G. What is an Aparatus?, in: Agamben, G. (2009), p. 14. 


\section{МИШКО ШУВАКОВИЋ}

интерактивни хетерогени скуп кога чине догађаји и односи са уметничким и вануметничким ентитетима у неком појединачном облику живота - жаргонски редуктивно речено: у животној ситуацији.

У савременој уметности је однос уметничког и вануметничког сасвим релативизован и, што је важно нагласити, пропустан. Уметничко и вануметничко могу заменити своја места али и функције без посебних драматичних последица - као што је то било у време првобитних колажа, монтажа и редимејда. На пример, однос уљане боје и канапа у Пикасовим (Pablo Picasso) кубистичким колажима, однос графичког знака и фотографске слике у новинским фотомонтажама Џона Хартефилда (John Heartfield) или изабрани свакодневни употребни предмети (точак бицикла, лопата, писоар, путна торба) у редимејдима Марсела Дишана (Marcel Duchamp). Диспозитив је пре свега материјална констелација којом се успостављају и показују ефекти уметничке праксе, праксе којом се процесуирају односи између потенцијалних статичних или динамичних ентитета унутар специфично конструисаних контекста у уметности, култури, друштву. Зато, диспозитив уметности повезује три битна а различито структрурирана поља политизације уметности: продукцију, дистрибуцију и рецепцију 12 односа између техне, епистеме и афекта која се уписују на место традиционално схваћеног уметничког дела.

Другим речима, са новомедијским и перформативним савременим уметничким праксама се прелази са праксе дела на праксу односа и, затим, са праксе односа на праксу процесуираних односа. Погледајте таблицу!

\begin{tabular}{|l|l|l|}
\hline инваријантно дело & потенцијални однос & процесуирани односи \\
- предмет & - инсталација & - новомедијска \\
- ситуација & - амбијент & - перформерска \\
- догађај & & производња и дистрибиција \\
& & чулно-концептуалног \\
\hline
\end{tabular}

Таблица 2 Дело - однос. Процесуирани односи

Дело се поставља као оно што је аутономно у односу на дистрибуцију, рецепцију и тиме политику. Дело је кодирано као потенцијална универзалност. Дистрибуција и рецепциja су тада као изведбене политике уметности спољашње у односу на дело. Оне су друштвене, економске, политичке и естетске ситуације у које се дело може увести и сместити према тренутним потребама појединца или друштва.

12 Rockhill, G. The Social Agencies of Radical History, in: Rockhill, G. (2014), p. 236. 


\section{МИШКО ШУВАКОВИЋ}

Насупрот инваријантној поставци уметничког дела потенцијалним односом се омогућава однос уметности као аутономне праксе према политици уметности и политизацији уметности у односу на микро или макро поредак света:

„Уметничко деловање ... настоји отворити нове путеве и отклонити препреке на неким пролазима те успоставити однос између раздвојених разина стварности." 13

Политика се пропозиционира потенцијалним односом и, затим, уводи се у стварни однос. А, процесуирани односи су уметнички рад (art labour) на чулно-концептуалним пакетима који немају стабилну форму или стабилну позицију - они су већ у измени која је политика променљивих појединачних облика живота. Процесуирани односи су координате ${ }^{14}$ политике. Они понекад изгледају као сам политика, мада, у ствари, ништа није политичко у себи ${ }^{15}$, већ по модалитетима процесуирања односа у продукцији, дистрибуцији и рецепчији уметности унутар културе и друштва. Процесуирањем односа се у производном и дистрибуционом смислу баве новомедијске и перформерске уметничке праксе тако што успостављају променьиве и трансформативне односе између раздвојених разина стварности које су саме опет у процесуирању између друштвених антагонизама $и$ конфликта.

\section{Разрада проблематике}

У једном често цитираном тексту Валтера Бењамина (Walter Benjamin) постоји сугестиван исказ којим се говори о историјски вођеном механизму промене људског опажања: „У оквирима великих историјских периода мења се, са целокупним начином живота људских колектива, и начин њиховог чулног опажања."16 Оно са чим се данас сусрећемо јесте „либерална теза” да у оквирима малих, нестабилних и отворених интервала унутар друштвене савремености флексибилно се мења, са начином живота људских колектива, и начин производње услова њиховог чулног опажања и, додајмо, људске чулности. Разлика између Бењаминовог тврђења

13 Bourriaud, N. (2013) Relacijska estetika / Postprodukcija. Kultura kao scenarij: kako umjentost reprogramira suvremene svijet, Zagreb: Biblioteka Refleksije, Muzej suvremene umjetnosti, p. 12.

14 Rockhill, G. Titillating Tautologies and Sobering Demarcations, in: Rockhill, G. (2014), p. 166.

15 Ranciere, J. Wrong: Politics and Police, in: Ranciere, J. (1999), p. 32.

16 Benjamin, W. Umetničko delo u veku svoje tehničke reprodukcije, u: Benjamin, W. (1974), str. 120. 


\section{МИШКО ШУВАКОВИЋ}

и „либералне” актуелизујуће ревизије његовог исказа је у указивању на:

1. разлику између великих историјских периода и малих нестабилних и отворених периода савремености,

2. разлику између промене и флексибилног мењања, и на

3. разлику између промене чулног опажања и производње, размене и рецепције услова чулног опажања, односно, процесуирања чулног опажања; при чему, чулно опажање није само усмереност на специјализовано чуло већ на артикулацију чулности телесно-бихејвиоралне индивидуалности и њеног колективног позиционирања у уметности, култури и друштву.

Назначена линија од Бењаминовог описа спорог или дуготрајног процеса акумулираних промена ка опису брзог и многоструког процесуирања у малим нестабилним и отвореним временским интервалима савремености указује на кретање од „поступне и дубоке историје медија” као историје еволуција техничких и технолошких диспозитива ка мултипликацији променљивих и фрагментираних медијских склопова у савремености.

Мултипликација, данас, указује на губитак разлика између индивидуалних конзистентних медија због тотализујуће дигитализације:

„Дигитална технологија чини релативно једноставним за дизајнере да хибридизују различите медије.”17

Долази до превазилажења медија као „посредничке кохерентне направе”. Диспозитиви постају програмабилне, а то значи тренутно изведбене инфраструктуре усмерене на

\begin{tabular}{|l|l|l|l|}
\hline $\begin{array}{l}\text { авангардни појам нових } \\
\text { медија }\end{array}$ & $\begin{array}{l}\text { неоавангардни } \\
\text { појам нових } \\
\text { медија }\end{array}$ & $\begin{array}{l}\text { авангардни, } \\
\text { неоавангардни } \\
\text { или } \\
\text { постмодерни } \\
\text { појам нових } \\
\text { медија }\end{array}$ & $\begin{array}{l}\text { савремени појам } \\
\text { нових медија }\end{array}$ \\
\hline $\begin{array}{l}\text { деконтекстуализација и } \\
\text { меконтекстуализација }\end{array}$ & $\begin{array}{l}\text { отварање или } \\
\text { проширивање } \\
\text { аутономног } \\
\text { медија ка } \\
\text { другом или } \\
\text { другим } \\
\text { медијима }\end{array}$ & $\begin{array}{l}\text { ремедијализација } \\
\text { као извођење } \\
\text { односа између } \\
\text { старих и нових } \\
\text { медија }\end{array}$ & $\begin{array}{l}\text { програмибилни } \\
\text { медији }\end{array}$ \\
\hline $\begin{array}{l}\text { употреба медија } \\
\text { специфичног за једну } \\
\text { уметност у другој } \\
\text { уметности }\end{array}$ & $\begin{array}{l}\text { интермедијално } \\
\text { тіхед тедіа } \\
\text { проширени } \\
\text { медији } \\
\text { мултимедијално }\end{array}$ & $\begin{array}{l}\text { ремедијализација } \\
\text { као присвајање } \\
\text { старих медија од } \\
\text { нових медија или } \\
\text { присвајање } \\
\text { нових медија од } \\
\text { старих медија }\end{array}$ & $\begin{array}{l}\text { механички рачунари } \\
\text { аналогии рачунари } \\
\text { дигитн рачунари } \\
\text { дигалне мреже }\end{array}$ \\
\hline
\end{tabular}

Таблица 3 Дефиниције нових медија

17 Bolter, J. D. (2007) Remediation and the language of new media, Northern Lights: Film and Media Studies Yearbook, Volume 5, p. 27. 
производњу савремености у процесима комуникације, репрезентације или ситуирања догађаја за функције естетске контекстуализоване размене и рецепције.

Мора се, зато, размотрити концепт „нових медија” у његовој историјској и актуелној перспективи! Таблица 3 нуди четири историјска модела „нових медија”.

Појам "нови медији” у авангардним уметностима означава уметничке праксе засноване на увођењу „нових” или „до тада некоришћених” медија у традиционално дефинисани медијски идентитет унутар појединих уметничких дисциплина. Новим медијима се називају различите техно-уметничке праксе засноване на иновацијском раду са уметничким или вануметничким медијима у специфичним контекстима уметности и културе. Новомедијском уметничком праксом се именују увођења нестандардног медија у стандардизовану и обичајно затворену тј. аутономну уметничку дисциплину. Новим медијима се називају увођења фотографског, филмског или видео рада у контексте сликарства и скулптуре, односно, музике и поезије. На пример, филмски експерименти америчко-француског дадаисте и надреалисте Мен Реja (Man Ray) је истраживачки рад у контексту „новог медија". С обзиром да он исходишно долази из контекста авангардних ликовних уметности, његови филмски експерименти (филм: Le Retour A La Raison, 1923) за традиционалне ликовне - мануелне - уметности су новомедијска пракса. Филм се редефинише као нови медиј тиме што се уводи у контекст уметничких продукција нефилмске, али експерименталне уметности сликарства и скулптуре. Тиме се сликарство и скулптура отварају ка новомедијском раду. Слично се може указати на иновативне технике у фотографији - фотографије начињене без фотографског апарата: Мен Рејеве „рајографије” или Ласло Мохоли Нађеви (Laszlo Moholy-Nagy) „фотограми”. Реч је о релативизацији дисциплинарних и медијских граница чиме се покреће нова политика дистрибуције чулности механичким медијем филма у контексту мишљења и делања унутар мануелног медијског контекста сликарства. У авангардама је дошло до употребе, на пример, једног медија (филм, фотографија) изван матичног контекста њихове продукције, дистрибуције и рецепциje. Разлика између биоскопског и галеријског филма је, зато, у бити разлика створена изменом контекста презентације дела и тиме изменом услова рецепције. Није реч само о поетичкој тј. стваралачкој радикализацији уметничког дела већ о политици уметности која се заснива око трансформације продукције, дистрибуције и рецепције уметности у контексту културалних институција. Реч је о трансформационом 
МИШКО ШУВАКОВИЋ

авангардном диспозитиву уметности, односно, о авангардним диспозитивима уметности.

„Новим медијима” се називају и неоавангардна експериментална истраживања са односима нових тј. отворених или проширених медија у односу на традиционално дефинисане мономедијске праксе:

„Медиј је почетно станиште објектног. Услов опажања и опажено уз услов да може бити средство. Иако почиње конкретним, медиј су и сва она средства која би могла бити употребљена... Медиј садржи однос посредника према посредованом које је такође посредник према посредованом."'18

„Новим медијима” се, зато, за разлику од „старих-мономедија" називају, на пример, и све оне интермедијске и хибридне уметничке праксе које настају комбинацијом више медија (mixed media, мултимедија, полимедија, проширени медији итд). Хибридизација медија је била битна за неоавангардне праксе педесетих и шездесетих година двадесетог века, да би у домен еманципованог експерименталног уметничког образовања ${ }^{19}$ била уведена у седамдесетим годинама двадесетог века. Овде синтагма „хибридизација медија” означава успостављање више од једног разликујућег медија у процесу стварања или комуницирања уметничке идеje и тиме дела. Уметничко дело као уметнички диспозитив се не може свести на један кохерентан медијски узорак-комад или хомогени медијски ефекат. У логику медијског рада је уграђен поступак разликовања те чулни ефекат разлике. Поступак медијског разликовања се остваривао отварањем једног медија ка другим медијима или медијским ефектима, односно, неуобичајеним инетрвенцијама унутар мономедијског система. Један сасвим рани пример је дело Нам Џун Пајка Зен за ТВ (1963). Пајков рад је заснован на ТВ пријемнику који прима регуларни програм - телевизијска слика се деформише електронски произведеном линијом која делује као сметња у пољу технички нормиране телевизијске дистрибуције чулности - чулне појавности слике. Интермедијарним се у контексту неоавангарди назива кретање од једног медија ка другом или увођење једног медија у други. На пример, амерички филмски експериментатор Стен Брекиџ (Stan Brakhage) обрађује целулоидну филмску

18 Radovanović, V. (1977) Mediji i kriteriji, Delo br. 4 Godina XXIII, Beograd, str. 1.

19 Buffalo Heads: Media Study, Media Practice, Media Pioneers, 1973-1990, eds. Vasulka, W. and Weibel, P. (2008), Karlsruhe: ZKM Center for Art and Media Karlsruhe and Cambridge MA: The MIT Press. 
траку мануелним осликавањем фрејмова филма (Mothlight, 1963). Нарушавала се граница између филмског и сликарског уметничког рада. Мултимедијално у неоавангардама је означавало конструкције сложеног, најчешће, механичког или аналогног техничког система помоћу кога су се остваривали различити, најчешће аудио и визуелни, ефекти који се не могу свети на продукције ефеката једне медијске технике. Мултимедијално је водило од медија као техничке направе ка медију као технолошком систему - систему направа - у редистрибуцији чулног (Нам Џун Пајк, Шуја Абе /Shuya Abe/, Видео синтисајзер, 1969-1992). Отварање медија, интермедијарно или мултимедијално су продукцијске праксе у којима се суочавају техне и епистема. То значи да конструисање, упошљавање, организовање и контрола различитих, уобичајено неповезаних медија не може бити само реализација нове техничке потенцијалности, а да се не покрену питања о врсти и смислу знања о новој чулној дистрибуцији која се уводи у јавну рещептивну сферу. Тиме се чулна дистрибуција и рецепција доживљавала као нови политички поредак за тело или тела у узорцима облика живота током излагања и презентовања новомедијског дела. За неоавангардне уметнике после Другог светског рата ново медијске праксе су биле, с једне стране, реализације утопијских пројекција авангарде о новом јединству уметности и технологије, а са друге стране, биле су увођење уметника у праксе комерцијализације нових технологија које су постале доступне масовној потрошњи изван специјализованог научно-технолошког лабораторијског рада. Извесни уметници неоавангарди су изгледали као научници тј. специјализовани конструктори (Едвард Ихнатович /Edward Ihnatowicz/, Владо Боначић, Зоран Радовић), а други као потрошачи или неспецијализовани корисници (Нам Џун Пајк, Вали Експорт /Valie Wexport/) или мистични проналазачи (Џон Кејџ /John Cage/, Jозеф Бојс /Joseph Beuys/, Иван Ладислав Галета).

У савременом смислу новим медијима се називају оне уметничке праксе које су засноване на програмирању уметничког дела (компјутерска аналогна уметност, дигитална уметност, сајбер уметност, нано уметност, неуро-дигитална уметност, мрежна уметност, био-техно уметност, еколошка уметност). Одредница „нови медиј” за програмабилне уметничке праксе на нивоу експерименталног или корисничког рада је одлика новомедијске уметности у доба глобализма. Програмабилност се појављује као глобално тотализујућа пракса уређења и извођења уметничког диспозитива, најчешће, између високе и популарне културе. У контексту програмабилних уметности се губи разлика између продукције, дистрибуције и рецепције, пошто више није реч о уметнич- 
ком делу као завршеном „чврстом или монолитном комаду”, већ о перманентном протоку података који добијају посредством информацијско-физичког интерфејса различите учинке којима се постижу процесирани односи техничке потенцијалности, епистемолошке изведбености и афективног дејства на индивидуално или колективна тела. По Марку Б. Н.. Хансену (Mark B. N. Hansen) оно што нове медије данас чини заиста новим јесте улога стварног физичког рецептивног тела у процесу дистрибуције и рецепције ефеката флексибилне дигитализације и њених интерфејс функција. ${ }^{20}$ Реч је о улози тела у интеракцији са дигиталним системом и његовим интерфејсима - на пример, дела Џефри Шоа (Jeffrey Shaw) EVE (Extended Viryual Environment ${ }^{21}$, 1993) или Хироши Хомура (Hiroshi Homura), Јоко Иши (Yoko Ishii) и NTT Solution Laboratiories (It's fire, you can touch it, 2008). Паралелно термину „нови медији”22 може се користити и термин „метамедиј”23 како га је дефинисао Лев Манович. Термином метамедиј се идентификује „нови онтолошки статус“ тоталне материјалне флуидности остварене компјутерском мултимедијом и везом дигиталних компјутера у комуникацијске мреже. Термином „метамедиј” се, у контексту програмабилности, означава ситуација дигиталног рачунара који није више мономедиј, већ медиј који може потенцијално симулирати било који други традиционални или нови медиј, чак и самог себе: симулација компјутера компјутером. Зато Лев Манович инсистира да „Нови медиј” може изгледати као медиј, али да је у ствари то само површина. ${ }^{24}$

Нова компјутерска мултимедија реферира на старе медије као на основу или као на полазни узорак (sample) програмске симулације. У модернизму, проналаском нових механичких и електронских медија репродукције (од фотографског светлосно-хемијског бележења слике и фонографског бележења звука до електромагнетног синхроног бележења слике и звука) долази до акумулације медијских или техничких записа или репрезентација реалности у физичке и дигиталне архиве. Кључни интерес унутар модернизма, у време авангарде механичких медија, био је проналазак нових форми, тј. проналажење различитих начина да се хуманизира и објективизира потпуно страна тј. вештачка слика света ко-

20 Hansen, M. B. N. Between Body and Image: On the Newness of New Media Art, in: Hansen, M. B. N. (2004), p. 22.

21 CyberArts 2008 (2008), p. 176-177.

22 Drucker, J. Interactive, Algoritjmic, Networked: Aesthetics of New Media Art, in: eds. Chandler, A. and Neumark, N. (2006), p. 34-59.

23 Manovich, L. (2002), p. 33.

24 Manovich, L. (2002), p. 47-48. 
ју пружају механичке и тек настајуће електронске медијске технологије (фото апарат, филмска камера и пројектор, механички и електрични грамофон, радио). Напротив, програмабилни нови медиј више се не примењује на посматрање, регистровање и приказивање спољашњег света на нов начин него је усмерена ка новим начинима приступања и коришћења претходно медијски акумулираних података те њиховом софтверском обрадом и архивирањем. Метамедијска уметност и култура заснивају се на дигиталном компјутеру као битној технологији за обраду информација и заступање или симулацију, а то значи опонашање и предочавање, чулних ефеката свих других медија или историјски архивираних дигитализованих трагова (визуелних слика, аудиовизуелних снимака). Дигиталном уметношћу се, зато, омогућава бављење новим начинима приступања, апропријације и манипулисања информацијама (на пример, видео инсталација Силвије Колбовски /Silvia Kolbowski/, After Hiroshima Mon Amour, 2009) у техничком, епистемолошком и афективном смислу. Технике дигиталне уметности су, на пример, хипермедији, базе података, претраживачи, упоређивачи података, инструменти за обраду слике, визуализације и симулације, интерактивне технологије итд. Дигитална уметница или уметник који преузима функционалне и инструменталне компетенције информатичког радника не приступа материјалној реалности директно него користи медијске записе и заокупљен је претходно акумулираним записима и приказима, односно, могућностима њихове трансформације и преноса који репрезентује вештачки конструисан аудиовизуелни текст као индивидуално или колективно имагинарно у дистрибуцији чулног (на пример, Наташа Теофиловић: s.h.e., 2006). Долази до потпуне нестабилности и трансфигуративности у којој се инструментаријум друштвене борбе проводи унутар политике, науке или организације свакодневице на начин симулираног и дизајнираног дистрибуирања чулности у односу на референтне концептуалне потенцијалности или актуелизације диспозитива као процесуираног скупа хетерогених односа. Извесни уметници и теоретичари говоре, такође, о „тактичким медијима” као у случају групе Critical Art Ensemble (теоријско манифестна књига Дигитални отпор. Истраживања тактичког медиjа ${ }^{25}$ ). Кониепт тактичког медија или касније уведени појам тактичког умрежавања означава политизацију диспозитива медијског рада који није нужно уметнички, али који се презентује и инфраструктурама уметности. Овим се

25 Critical Art Ensemble (2001) Digital Resistance. Explorations in Tactical Media, New York: Autonomedia. 


\section{МИШКО ШУВАКОВИЋ}

указује на релативизовање односа уметничке, културалне и друштвене производње, дистрибуције и рецепиије медијских учинака ма које врсте. При томе, приступ, на разини мрежа, може бити отворен (ореп source) или контролисан власничким правом (password rights), односно, неконтролисан хакерским упадима постављеним на комерцијалној, етичкој, политичкој или забавној разини. Другим речима, поље програмабилног рада је отворило нови политички и економски простор који нуди отворене или контролисане извесне и неизвесне аспекте организације и извођења облика свакодневног живота.

\section{Закључак}

Намера ове кратке еклектичне студије је да на два плана расправи политички статус „нових медија“:

1. На разини трансформације уметничког дела у процесуирани уметнички диспозитив посредством повезаности техничких средства, потенцијалног интервентног знања и афективног дејства у пољу промене политике продукције у политику режима продукције, дистрибуције и рецепције чулних учинака.

2. На разини редефинисања појмовног бинарног пара „медиј” - „нови медиј” који се дисперзивно расипа из бинарности (старо - ново, + -) у тактичку ситуацију онтологизације многострукости ${ }^{26}$ која се да предочити сложеним процесуирањима жудње оријентисане ка мишљењу, чулности и кретању иманентном многострукости савремених облика живота.

Указивањем на ова два плана конкретизује се полазна хипотеза о битности увођења троугла: техне, епистема, афект као онтолошке основе за теоретизацију новомедијских уметничких пракси и њиховог релативног односа са праксама културе и друштва које нужно одређују сваку друштвену борбу.

\section{ЛИТЕРАТУРА:}

Adorno, T. W. (1979) Estetička teorija, Beograd: Nolit.

Agamben, G. (2009) What is an Aparatus? and Other Essays, Stanford CA: Standford University Press.

At a Distance - Precursor to Art and Activism on the Internet, eds. Chandler, A. and Neumark, N. (2006), Cambridge MA: The MIT Press.

Benjamin, W. (1974) Eseji, Beograd: Nolit.

26 Hallward, P. Badiou's Ontology, in: Hallward, P. (2003), p. 81. 


\section{МИШКО ШУВАКОВИЋ}

Bolter, J. D. (2007) Remediation and the language of new media, Northern Lights: Film and Media Studies Yearbook Volume 5, p. 25-37.

Bourriaud, N. (2013) Relacijska estetika / Postprodukcija. Kultura kao scenarij: kako umjentost reprogramira suvremene svijet, Zagreb: Biblioteka Refleksije, Muzej suvremene umjetnosti.

Buffalo Heads: Media Study, Media Practice, Media Pioneers, 19731990, eds. Vasulka, W. and Weibel, P. (2008), Karlsruhe: ZKM Center for Art and Media Karlsruhe and Cambridge MA: The MIT Press.

Critical Art Ensemble (2001) Digital Resistance. Explorations in Tactical Media, New York: Autonomedia.

Cyber Arts 2008. International Compedium - Prix Ars Electronica 2008 (2008), Ostfildern: Hatje Cantz.

Hallward, P. (2003) Badiou. A Subject to Truth, Minneapolis: University of Minnesota Press.

Hansen, M. B. N. (2004) New Philosophy for New Media, Cambridge MA: The MIT Press;

http://processingjs.org. 28.07.2015.

Kittler, F. (2010) Optical media: Berlin Lectures 1999, Cambridge: Polity.

Manovich, L. (2002) The Language of New Media, Cambridge MA: The MIT Press, 2002.

Modernism, Criticism, Realism, eds. Harrison, C. and Orton, F. (1984), Cambridge: Harper\&Row Publishers.

Power Knowledge: Selected Interviews \& Other Writings 1972-1977, ed. Gordon, C. (1980), New York: Pantheon Books.

Radical Thought in Italy. A Potential Politics, eds. Virno, P. and Hardt, M. (1996), Minneapolis: University of Minnesota Press.

Radovanović, V. (1977) Mediji i kriteriji, Delo br. 4 Godina XXIII, Beograd, str. 1-81.

Ranciere, J. (1999) Dis-agreement. Politics and Philosophy, Minneapolis: University of Minnesota Press.

Rancière, J. (2004) The Politicos of Aesthetics. The Distribution of the Sensible, London: Continuum.

Rockhill, G. (2014) Radical History\&The Politics of Art, New York: Columbia University Press.

Stiegler, B. (1998) Technics and Time 1. The Fault of Epimetheus, Stanford CA: Stanfo

Uvod u Heideggera (1972) Zagreb: Centar za društvene djelatnosti omladine RK SOH.

Wittgesntein, L. (1986) Philosophical Investigations, Oxford: Basil Blackwell. 
МИШКО ШУВАКОВИЋ

\author{
Miško Šuvaković \\ University of Arts in of Belgrade, Faculty of Music
}

SKETCHES FOR THE THEORY OF NEW MEDIA

\begin{abstract}
The text "Sketches for the theory of new media" suggests open problems for eclectic discussion of new media in the field of contemporary aesthetics and art theory; it indicates the status of new media artwork and the replacement of the concept of artwork by artistic apparatus. More precisely, 'new media' denotes different artistic practices that are based on innovative working with artistic or extra-artistic media. 'New-media artistic practice' denotes introducing non-standard media into a standardized and customarily closed art discipline. For instance, new media may signify introducing photography, film or video into the respective contexts of painting, sculpture or music. 'New media' also denotes experimental investigations of the relations between various traditional and new media within traditionally defined mono-medium practices. Therefore, 'new media' likewise denotes all those intermedia and hybrid art practices that emerge in combinations of different kinds of media (the mixed media, multimedia, poly-media, extended media, art and technology, computer art, cyber art, tactical media, etc). Whereas the hybridization of media was important for the 1950s and '60s neo-avant-garde practices, it was introduced into art education only in the seventies. 'New media' denotes precisely those art practices that are based on artwork-programming (computer art, digital art, cyber art). In parallel with 'new media', one may also use the term 'meta-media', as defined by Lev Manovich. Meta-media is identified with computer multimedia and digital communication networks. The new-media art is no longer interested in observing and presenting the outer world in a new way but in finding new ways to approach and use data previously accumulated in the media. Meta-media art and culture are based on the digital computer as a technology vital for processing, representing or simulating information, which means imitating and positing the sensory effects of all other media.
\end{abstract}

Key words: new media, apparatus, processing, politics, avant-guarde, neo-avant-guarde, contemporary art 